\title{
IMPLEMENTASI BUDAYA SEKOLAH DALAM MEWUJUDKAN PENDIDIKAN KARAKTER DI SD NEGERI 19 AMBON
}

\author{
Nathalia Yohana Johannes ${ }^{1}$, Samuel Patra Ritiauw ${ }^{2}$, Hartini Abidin ${ }^{3}$ \\ Program Studi Pendidikan Guru Sekolah Dasar ${ }^{1.2 .3}$ \\ Universitas Pattimura \\ email: nathaliayjohannes@gmail.com
}

\section{ARTICLE INFO}

Article History:

Accepted 9-03- 2020

Available online 7-04- 2020

Keywords:

Pembiasaan, Budaya

Sekolah, Pendidikan

Karakter, Siswa

\section{ABSTRAK}

Penelitian ini bertujuan untuk mengetahui Implementasi budaya sekolah dalam mewujudkan pendidikan karakter di SD Inpres 19 Ambon, faktor penghambat dan upaya yang dilakukan untuk mengatasi kendala implementasi budaya sekolah dalam mewujudkan pendidikan karakter di SD Inpres 19 Ambon. Metode yang digunakan dalam penelitian ini adalah metode penelitian kualitatif, dengan teknik pengumpulan data secara trianggulasi. Data dilakukan secara terus-menerus sampai datanya jenuh. Dalam penelitian ini, subjek penelitian adalah kepala sekolah, guru, dan siswa yang berada di SD Inpres 19 Ambon. Penentuan subjek dalam penelitian ini berdasarkan pertimbangan sebagai berikut: (1) kepala sekolah dianggap sebagai pihak yang paling mengetahui situasi dan kondisi terkait apa yang ada di sekolah, (2) tiga guru kelas karena guru tersebut paling sering terlibat langsung dengan pendidikan anak di kelas, dan (3) beberapa siswa dari kelas III-V yang dianggap mewakili tiap kelas di SD Inpres 19 Ambon. Hasil penelitian terlihat bahwa implementasi budaya sekolah melalui budaya religius, kemandirian, nasionalisme, budaya peduli sosial dan budaya peduli lingkungan mampu mewujudkan pendidikan karakter di SD Inpres 19 Ambon. 


\section{PENDAHULUAN}

Indonesia saat ini sedang dihadapkan pada persoalan karakter yang sangat serius dan perlu mendapat perhatian untuk dikaji. Pergeseran orientasi kepribadian yang mengarah pada berbagai perilaku amoral sudah demikian jelas dan nampak terjadi ditengah-tengah kehidupan bermasyarakat. Berbagai tindak kenakalan anak dan remaja seperti tawuran, menyalahgunakan narkotika, membolos, dan kenakalankenakalan lain serta banyak tindakan kriminal dapat dengan mudah dijumpai melalui tayangan televisi maupun secara langsung. Persoalan karakter bangsa di atas menjadi sorotan tajam masyarakat. Sorotan itu tertuang dalam berbagai tulisan di media cetak, wawancara, dialog dan gelar wicara di media elektronik. Hal ini menunjukkan bahwa Indonesia berada pada krisis karakter.

Agustian (2008: 8) mengemukakan bahwa menurut analisis Emotional Spiritual Quotient (ESQ), ditengarai ada enam krisis moral di tengah-tengah masyarakat Indonesia, yaitu krisis kejujuran, krisis tanggung jawab, krisis tidak berfikir jauh kedepan, krisis displin, krisis keberasamaan, dan krisis keadilan. Sebenarnya, masalah-masalah tersebut bukan hanya dialami oleh Indonesia, tetapi juga bangsa-bangsa lain di dunia. Amerika Serikat misalnya, telah menyadari bahwa terjadi kemerosotan moral sejak tiga dekade yang lalu dan hal tersebut membangkitkan kesadaran aksi untuk membenahi warganya melalui pendidikan karakter di sekolah.

Upaya pengembangan pendidikan karakter secara eksplisit telah diamanatkan dalam Undang Undang Dasar Republik Indonesia Nomor 20 Tahun 2003 menegaskan bahwa;

"Pendidikan nasional bertujuan mengembangkan kemampuan dan membentuk watak serta peradaban bangsa yang bermartabat dalam rangka mencerdaskan kehidupan bangsa, bertujuan untuk berkembangnya potensi peserta didik agar menjadi manusia yang beriman dan bertakwa kepada Tuhan Yang Maha Esa, berakhlak mulia, sehat, berilmu, cakap, kreatif, mandiri, dan menjadi warga negara yang demokratis serta bertanggung jawab" (Yaumi, 2014).

Mencermati tujuan pendidikan nasional, yakni mengembangkan kemampuan dan membentuk watak serta peradaban bangsa, apabila pendidikan tidak mampu membentuk watak (character) bisa dikatakan pendidikan tersebut tidak berfungsi dengan baik. Pendidikan yang berfungsi dengan baik tidak hanya menghasilkan siswa-siswa yang cerdas, tetapi juga cakap, kreatif, dan bernilai.

Pendidikan karakter merupakan sebuah usaha untuk mendidik anak-anak agar dapat mengambil keputusan dengan bijak dan mempraktikkan dalam kehidupan sehari-hari, sehingga mereka dapat memberikan kontribusi positif kepada masyarakatnya, Wiyani (2012: 24). Sementara itu, Lickona (2004: 53) berpendapat bahwa pendidikan karakter adalah pendidikan yang menitikberatkan dalam hal pembentukan kepribadian melalui pengetahuan tentang moral (moral behaviour) yang dihasilkan terlihat dalam tindakan nyata seseorang, yaitu tingkah laku yang baik, jujur, bertanggung jawab, menghormati hak orang lain, dan kerja keras. Pendidikan 
karakter adalah upaya terencana untuk membantu orang untuk memahami, peduli, dan bertindak atas nilai-nilai moral dan etika (Lickona, 1992) "character education is the deliberate effort to help people understand, care about, and act upon core ethical values." Hal ini berarti bahwa pendidikan karakter merupakan upaya yang disengaja untuk membantu orang memahami, peduli, dan bertindak berdasarkan nilai-nilai etika inti.

Saripudin dan Komalasari (2017: 303) mengemukakan bahwa pendidikan karakter merupakan suatu habit, maka pembentukan karakter seseorang itu memerlukan communities of character yang terdiri dari keluarga, sekolah, institusi keagamaan, media, pemerintah dan berbagai pihak yang memepengaruhi nilai-nilai generasi muda. Bagi Lickona (1996: 93), ada beberapa alasan yang sangat mendesak mengapa pendidikan karakter bangsa sangat diperlukan di sekolah. Adapun alasannya sebagai berikut: pertama, apabila ingin menjadi manusia seutuhnya, maka kita membutuhkan karakter yang baik. Karakter yang baik membutuhkan pikiran, hati, dan kemauan yang kuat sebagai contoh jujur, empati, perhatian, ketekunan, disiplin, diri sendiri, dan dorongan moral. Kedua, sekolah merupakan tempat yang baik untuk mengajarkan, menyebarluaskan nilai-nilai karakter bangsa. Ketiga, pendidikan karakter sangat penting untuk membangun sebuah masyarakat yang bermoral. Ini berarti pendidikan karakter sangat penting ditanamkan sejak dini.

Tujuan pendidikan karakter secara umum menurut Zubaedi (2015:18) yakni, pertama berfungsi dalam membentuk dan mengembangkan potensi siswa agar berfikir baik, berhati baik, dan berperilaku baik sesuai dengan falsafah hidup Pancasila. Kedua, berfungsi untuk memperbaiki dan memperkuat peran keluarga, satuan pendidikan, masyarakat, dan pemerintah agar dapat berpartisipasi dan bertanggung jawab dalam mengembangkan potensi warga Negara dan membangun bangsa menuju bangsa yang maju. Ketiga berfungsi memilah budaya bangsa sendiri serta menyaring budaya bangsa lain yang tidak sesuai dengan nilai budaya dan karakter bangsa yang bermartabat. Dengan adanya ketercapaian ketiga tujuan pendidikan karakter seperti yang dipaparkan di atas maka seseorang dapat berperilaku sesuai dengan falsafah Pancasila, berpartisipasi dalam lingkungan masyarakat, dan bertanggung jawab sebagai warga Negara yang baik. Pendidikan karakter juga memiliki tujuan untuk pembentukan karakter siswa, hal ini sejalan dengan pendapat Agus (2012: 22), bahwa pendidikan karakter bertujuan untuk pembentukan dan pembangunan pola pikir, sikap, dan perilaku siswa supaya dapat menjadi pribadi yang positif, berakhlak karimah, berjiwa luhur, dan bertanggung jawab.

Secara sederhana dapat dikemukakan bahwa tujuan dari pendidikan karakter adalah untuk membentuk dan mengembangkan potensi siswa agar berperilaku baik sesuai dengan falsafah Pancasila, dapat berpartisipasi di lingkungan masyarakat dan bertanggung jawab sebagai warga Negara yang baik. Selain itu pendidikan karakter bertujuan untuk pembentukan karakter siswa sehingga terbentuk karakter yang baik.

Menurut Hamalik (2008: 150), penting sekali mengenal dan memahami peserta didik dengan seksama agar guru dapat menentukan dengan seksama bahanbahan yang akan diberikan, menggunakan prosedur mengajar yang serasi. Sementara itu Lickona (2013: 244) mengatakan bahwa metode penting dalam pendidikan nilai 
yaitu adanya peran guru sebagai teladan dan pembimbing, membangun masyarakat yang bermoral, menciptakan suasana kelas penuh dengan nilai-nilai saling menghargai dan bertanggung jawab. Peserta didik memiliki kemampuan untuk tumbuh dan berkembang sendiri dalam interaksi pendidikan antara peserta didik dan pendidik tidak harus selalu diberi atau dilatih, mereka dapat menemukan dan melatih dirinya sendiri, (Saripudin, 2010: 33). Sejalan dengan itu, Kesuma (2013: 41) menyatakan bahwa lembaga-lembaga yang "sehat" dapat memberikan pengaruh yang mendidik, dan sebaliknya. Dari berbagai pendapat ini maka untuk mendidik siswa, guru terlebih dahulu harus memahami karakter siswa melalui metode keteladan yang dapat dijadikan sebagai contoh siswa untuk menerapkan karakter baik tersebut, metode lain juga bisa dilakukan melalui suatu pembiasaan yang dilakukan secara berkelanjutan.

Banyak hal yang dapat dilakukan untuk meningkatkan mutu pendidikan. Salah satunya adalah membangun budaya sekolah dengan baik. Budaya sekolah merupakan kultur organisasi dalam konteks persekolahan. Menurut Uyoh, dkk (2006: 65), definisi budaya sekolah belum diperoleh kesatuan pandangan. Terminologi budaya sekolah masih disamakan dengan "iklim atau ethos". Konsep budaya sekolah masuk ke dalam pendidikan itu pada dasarnya sebagai upaya untuk memberikan arah tentang efisiensi lingkungan pembelajaran, lingkungan dalam hal ini dapat dibedakan dalam dua hal (1) lingkungan yang sifatnya alami sesuai dengan budaya siswa dan guru, (2) lingkungan artificial yang diciptakan oleh guru atau hasil interaksi antara guru dengan siswa

Budaya sekolah adalah karakteristik khas sekolah yang dapat diidentifikasi melalui nilai yang dianutnya, sikap yang dimilikinya, kebiasaan-kebiasaan yang ditampilkannya, dan tindakan yang ditunjukkan oleh seluruh personel sekolah yang membentuk satu kesatuan khusus dari sistem sekolah, inilah yang dikemukakan oleh Triatna (2005: 102). Tujuan dari budaya sekolah adalah untuk membangun suasana sekolah yang kondusif melalui pengembangan komunikasi dan interaksi yang sehat antara kepala sekolah dengan peserta didik, pendidik, tenaga kependidikan, orang tua peserta didik, masyarakat dan pemerintah. Menurut Anggarini (2017: 151), budaya sekolah memegang peranan penting dalam penanaman nilai pendidikan karakter di sekolah.

Konsep kultur dalam dunia pendidikan berasal dari kultur tempat kerja di dunia industri, yaitu situasi yang memberikan landasan dan arah untuk berlangsungnya suatu proses secara efektif dan efisien (Zamroni, 2000: 134). Penerapan istilah kultur atau budaya pada organisasi dalam hal ini termasuk lembaga pendidikan dapat dikatakan relatif baru. Sebelumnya sekitar pada awal tahun 1960-an digunakan istilah "Organizational Culture" yang sinonim dengan "climate"atau suasana yang selanjutnya pada tahun 1970-an istilah serupa "corporate culture" mulai digunakan dan menjadi populer. Dengan diterbitkannya buku Deal dan Kennedy yang berjudul Coporate Culture: The Rites and Rituals of Corporate Life.

Kultur organisasi adalah istilah yang mudah untuk diucapkan tetapi sulit di definisikan sebagaimana halnya yang dinyatakan Robbin (1993) mengungkapkan bahwa: "Organizationla culture is one of those topics about which many people will 
say, 'Oh yeah, I know what you mean but one of that is quite difficult to define in any specific form". Dalam mendefinisikan kultur organisasi cendrung dimaknai oleh anggota organisasi sebagai sistem yang dianut yang membedakan suatu organisasi dengan organisasi lainnya. Jones (1995) dalam Tirahardja, dkk (1994: 56) memberikan definisi kultur organiasi dan karakteristik budaya organisasi. Menurut Jones, kultur organisasi adalah seperangkat nilai yang mengontrol anggota organisasi dalam berinteraksi baik dengan sesamanya maupun dengan orang-orang di luar organisasi. Sedangkan karakteristik kultur organisasi meliputi nilai-nilai, kontrol koordinasi dan motivasi, etika, dan proses disain organisasi. Nilai dalam hal ini dapat dikategorikan atas nilai: idielogi, politik, ekonomi, sosial, budaya, militer keamanan dan agama senada dengan itu Tilaar, (2000: 67) mengungkapkan budaya sekolah adalah nilai-nilai dominan yang didukung oleh sekolah atau falsafah yang menuntun kebijakan sekolah terhadap semua unsur dan komponen sekolah termasuk stakeholders pendidikan, seperti cara melaksanakan pekerjaan di sekolah serta asumsi atau kepercayaan dasar yang dianut oleh personil sekolah.

Langgulung (2007:67) mendefinisikan bahwa budaya sekolah merujuk pada suatu sistem nilai, kepercayaan dan norma-norma yang diterima secara bersama, serta dilaksanakan dengan penuh kesadaran sebagai perilaku alami, yang dibentuk oleh lingkungan yang menciptakan pemahaman yang sama diantara seluruh unsur dan personil sekolah baik itu kepala sekolah, guru, staf, siswa dan jika perlu membentuk opini masyarakat yang sama dengan sekolah. Sejalan dengan itu Dirto.dkk (1995:87) menjelaskan bahwa "budaya sekolah adalah karakteristik khas sekolah yang dapat diidentifikasi melalui nilai yang dianutnya, sikap yang dimilikinya, kebiasaankebiasaan yang ditampilkanya dan tindakan yang ditunjukan oleh seluruh personel sekolah yang membentuk suatun kegiatan khusus dari sistem sekolah". Budaya sekolah adalah sekumpulan nilai yang melandasi perilaku, tradisi, kebiasaan keseharian, dan simbol-simbol yang dipraktikkan oleh kepsek, guru, petugas admin, siswa, dan masyarakat sekitar sekolah. Budaya sekolah merupakan ciri khas, karakter atau watak, dan citra sekolah tersebut di masyarakat luas.

Dari beberapa penjelasan di atas dapat ditarik benang merah bahwa kultur sekolah sebagai " pola nilai-nilai, norma, sikap, mitos dan kebiasaan-kebiasaan yang terbentuk dalam perjalanan panjang suatu sekolah, dimana sekolah tersebut dipegang bersama oleh kepala sekolah, guru, staf, maupun siswa, sebagai dasar mereka dalam memahami dan memecahkan berbagai persoalan yang muncul di sekolah. Dengan kata lain bahwa kultur atau budaya sekolah dapat dikatakan sebagai pikiran, katakata, sikap, perbuatan, dan hati setiap warga sekolah yang tercermin dalam semangat, perilaku maupun simbol serta slogan khas identitas mereka.

Sesuai dengan Desain Induk Pendidikan karakter yang dirancang Kemendiknas (2010) strategi pengembangan pendidikan karakter dapat dilakukan melalui transformasi budaya sekolah (school culture) dan habituasi melalui kegiatan pengembangan diri (ekstrakurikuler ). Hal ini sejalan dengan pemikiran Berkowitz, (dalam Samani,dkk.2011) yang menyatakan bahwa: implementasi pendidikan karakter melalui transformasi budaya dan perikehidupan sekolah, dirasakan lebih efektif daripada mengubah kurikulum dengan menambahkan materi pendidikan 
karakter dalam muatan kurikulum.

Dalam kaitan pengembangan budaya sekolah yang dilaksanakan dalam kaitan pengembangan diri, Kemendiknas menyarankan melalui empat hal, yang meliputi : 1.Melalui kegiatan rutin, 2.Kegiatan spontan, 3.Keteladanan, dan 4.Melalui pengondisian. Secara substantif karakter terdiri dari 3 (tiga) nilai operatif, nilai-nilai dalam tindakan, atau unjuk perilaku yang satu sama lain saling berkaitan. Ketiga nilai tersebut adalah: pengetahuan tentang moral (moral knowing, aspek kognitif); perasaan berdasarkan moral (moral feeling, aspek afektif ); dan perilaku berlandaskan moral (moral action, aspek psikomotor).

Ada banyak faktor yang mempengaruhi terwujudnya pendidikan karakter di SD Inpres 19 Ambon. Hal ini berdasarkan hasil observasi dan wawancara terhadap guru dan kepala sekolah. Di SD Inpres 19 Ambon, budaya sekolah untuk mewujudkan karakter Peduli Sosial, Religius, Nasionalis, Kemandirian dan Peduli lingkungan belum berjalan dengan baik. Masih ada sikap siswa yang membully teman sekelasnya. Penggunaan gedung sekolah secara bersama (sekolah satu atap) sering menyebabkan perkelahian antar siswa. Selain itu dalam sikap, beberapa siswa masih kurang sopan terhadap orang yang lebih tua. Ada siswa yang acuh dan tak acuh serta ramai sendiri ketika ada teman melakukan presentasi di depan kelas. Dalam observasi juga ditemukan siswa yang pada saat mengerjakan tugas kelompok di kelas mereka tidak bekerja secara bersama-sama tapi mengerjakan tugas kelompok tadi secara pribadi.

Pada saat kegiatan Jumat Religius masih ada beberapa siswa tidak mengikutinya dengan baik. Masih ada yang bermain dengan temannya jadi tidak mendengarkan arahan yang diberikan guru pemateri. Pada saat upacara bendara masih ada beberapa siswa tidak mengikutinya dengan sungguh-sungguh. Kemudian masih ada siswa juga melakukan sesuatu misalnya tugas dikelas harus di bantu guru karena belum bisa mengerjakan secara mandiri atau sendiri. Dan juga masih adanya siswa yang belum sadar tentang kebersihan lingkungan sekolah. Siswa masih membuang sampah tidak pada tempatnya.

\section{METODOLOGI}

Penelitian ini menggunakan pendekatan penelitian kualitatif. Penelitian kualitatif didasarkan pada data yang berupa kata-kata dalam mendeskripsikan obyek yang diteliti dengan menggunakan pendekatan induktif. Metode penelitian kualitatif digunakana untuk meneliti pada obyek yang alamiah, dimana peneliti sebagai instrumen kunci. teknik pengumpulan secara trianggulasi analisis data yang bersifat induktif/kualitatif dan hasil penelitian kualitatif lebih menekankan makna dari pada generalisasi. Adapun lokasi penelitian ini berada di kota Ambon Provinsi Maluku tepatnya di Sekolah Dasar Inpres 19 Ambon yang berada di jalan Sultan Babullah. Sekolah tersebut sudah berupaya menanamkan nilai-nilai pendidikan karakter di sekolah. Sekolah tersebut memiliki visi "terbentuknya warga sekolah yang bertaqwa, cerdas, sehat, berkarakter dan berbudaya lingkungan" 
Dalam penelitian ini, subjek penelitian adalah kepala sekolah, guru, dan siswa yang berada di SD Inpres 19 Ambon. Penentuan subjek dalam penelitian ini berdasarkan pertimbangan sebagai berikut: (1) kepala sekolah dianggap sebagai pihak yang paling mengetahui situasi dan kondisi terkait apa yang ada di sekolah, (2) tiga guru kelas karena guru tersebut paling sering terlibat langsung dengan pendidikan anak di kelas, dan (3) beberapa siswa dari kelas III-V yang dianggap mewakili tiap kelas di SD Inpres 19 Ambon.

Teknik pengumpulan data merupakan cara-cara yang dapat dilakukan dan digunakan oleh peneliti untuk mengumpulkan data. Menurut Sugiyono (2012: 308), teknik pengumpulan data merupakan langkah yang paling strategis dalam penelitian karena tujuan utama dari penelitian adalah mendapatkan data. Dalam penelitian kualitatif, pengumpulan data dilakukan pada kondisi alamiah (natural setting), sumber data primer, dan teknik pengumpulan data lebih banyak pada observasi, wawancara mendalam, dan dokumentasi. Menurut Sugiyono (2012: 333) dalam penelitian kualitatif, data yang diperoleh dari berbagai sumber, dengan menggunakan teknik pengumpulan data yang bermacam-macam (triangulasi), data dilakukan secara terus menerus sampai datanya jenuh. Hal senada disampaikan Miles dan Huberman (Sugiyono, 2012: 337) yang menyatakan bahwa aktifitas dalam analisis data kualitatif dilakukan secara interaktif dan berlangsung secara terus menerus sampai tuntas, sehingga datanya sudah jenuh. Aktivitas dalam analisis data, yaitu Data Collection, data reduction, data display, dan data drawing/verification.

\section{HASIL PENELITIAN DAN PEMBAHASAN}

Pendidikan karakter adalah pendidikan budi pekerti, yaitu yang melibatkan aspek pengetahuan (cognitive), perasaan ( feeling), dan tindakan (action). Pendidikan karakter di sekolah dengan harapan dapat menjadikan siswanya memiliki sikap sopan santun, sesuai harapan bangsa, negara dan masyarakatnya. Karena pada dasarnya pendidikan karakter adalah pendidikan yang ingin memberikan pemahaman bahwa sifat-sifat terpuji tidak hanya dipelajari namun juga diaplikasikan serta mengetahui nilai dari sifat terpuji tersebut. Sehingga dimanapun seseorang itu berada ia tetap menjunjung tinggi akhlak mulia yang ada dalam dirinya. Dalam pendidikan karakter di sekolah, semua komponen (pemangku pendidikan) harus dilibatkan, termasuk komponen-komponen pendidikan itu sendiri, yaitu isi kurikulum, proses pembelajaran dan penilaian, penanganan atau pengelolaan mata pelajaran, pengelolaan sekolah, pelaksanaan aktivitas atau kegiatan ko-kurikuler, pemberdayaan sarana prasarana, pembiayaan, dan etos kerja seluruh warga sekolah/lingkungan. (Lestari dan Sukanti, 2016).

Implementasi budaya sekolah dalam mewujudkan pendidikan karakter di SD Inpres 19 Ambon telah berhasil, dilihat dari kenyataan yang ada di SD Inpres 19 Ambon telah mampu menyeimbangkan antara proses dan hasil sehingga memiliki daya tarik tersendiri ditengah-tengah masyarakat yang semakin hari semakin membutuhkan sekolah yang lebih menanamkan nilai karakter yang tidak hanya 
memperhatikan aspek kognitif tetapi juga pembinaan aspek afektif sehingga tidak mengakibatkan terjadinya kesenjangan antara pengetahuan dan pengalaman.

Berbagai hal yang mengindikasikan berhasilnya implementasi budaya sekolah dalam mewujudkan pendidikan karakter di SD Inpres 19 Ambon diantaranya sebagai berikut: (a) budaya religius; yaitu sikap dan perilaku yang patuh dalam melaksanakan ajaran agama yang diantutnya. Nilai karakter religius telah menjadi budaya sekolah di SD Inpres 19 Ambon misalnya kegiatan Jumat religius. Hal ini menunjukkan bahwa sekolah mengajak siswa untuk senantiasa mendekatkan diri pada Tuhan Yang Maha Esa, selain itu diadakan doa bersama setiap sebelum dan setelah pelajaran selesai. (b). Budaya nasionalisme. Sikap nasionalisme ditunjukan melalui sikap apresiasi budaya bangsa sendiri, menjaga kekayaan budaya, rela berkorban, unggul dan berprestasi, cinta tanah air, menjaga lingkungan, taat hukum, disiplin, menghormati keragaman budaya, suku dan agama. Kegiatan yang dilakukan sekolah adalah dengan melakukan upacara di hari Senin atau hari-hari besar selalu diperingati dengan upacara bendera oleh sekolah. Upacara bendera yang dilaksanakan setiap hari senin untuk menciptakan rasa nasionalisme di dalam diri peserta didik. Bersih lingkungan, lingkungan disekolah SD Inpres 19 Ambon sangat dijaga kebersihannya dengan cara adanya tugas piket yang dibagikan guru kelas untuk peserta didik dalam hal kebersihan kelas maupun kebersihan lingkungan. Kemandirian, yang ditanamkan yaitu pada saat proses pembelajaran peserta didik harus mengerjakan tugas secara mandiri dan tugas guru hanya mengarahkan apa yang harus dikerjakan kepada peserta didik. peduli sosial, sikap peduli yang ditanamkan disekolah adalah saling membantu satu sama lain jika ada yang membutuhkan pertolongan. Kegiatan-kegiatan tersebut sangat membantu untuk membentuk karakter peserta didik dan kerjasama antara warga sekolah yang baik sehingga budaya sekolah yang diterapkan berjalan dengan baik agar menjadikan peserta didik memiliki karakter yang diharapkan kedepannya ketika dia akan melanjutkan kejenjang sekolah yang lebih tinggi. (c). Menanamkan nilai kemandirian di dalam diri siswa dengan memberikan tugas secara mandiri kepada siswa. Tugas guru hanya membimbing siswa tersebut. Pemberian tugas kepada siswa dengan bimbingan dari guru maka siswa menjadi mandiri dalam bertanggung jawab terhadap tugas yang diberikan kepadanya. (d) Budaya peduli sosial yaitu sikap dan tindakan yang selalu ingin memberi bantuan bagi orang lain dan masyarakat yang membutuhkan. Untuk mengajarkan siswa-siswi lebih peduli kepada orang yang kurang mampu sekolah SD Inpres 19 Ambon memiliki kegiatan yaitu dengan melakukan donasi berupa uang atau makanan kepada mereka yang membutuhkan. Salah satu contoh kegiatan donasi yang dilakukan oleh sekolah adalah peduli gempa Palu dan Zigi. (e) Selain itu juga ada budaya peduli lingkungan yaitu kegiatan bersih lingkungan yang ada di SD Inpres 19 Ambon. Berdasarkan hasil wawancara dikemukakan bahwa: "pembiasaan bersih lingkungan dimulai dari cara sederhana yakni dibuatnya susunan tugas harian siswa yang bertanggung jawab untuk membersihkan kelas. Dengan dilakukannya pembiasaan bersih-bersih lingkungan bagi seluruh siswa untuk membersihkan lingkungan sekolah dan kelas setiap harinya maka disinilah terbentuk karakter siswa untuk memperhatikan kebersihan lingkungan sekolah. 
Dalam pelaksanaan budaya sekolah dan implementasinya untuk mewujudkan pendidikan karakter terdapat faktor pendukung dan penghambat. Faktor pendukung diantaranya orang tua, orang tua selalu membantu hal apapun yang dilakukan oleh sekolah berkaitan dengan hal yang positif. Dari hasil wawancara dikemukakan bahwa

"Dengan adanya pembiasaan yang positif pihak orang tua sangat mendukung kegiatan-kegiatan yang dilakukan sekolah. Misalnya kegiatan mengikuti lomba-lomba cerdas cermat, siswa merasa senang karena mereka bisa mengikuti lomba-lomba tersebut untuk mewakili sekolahnya. Dan orang tua sangat mendukung hal tersebut dengan memberikan dana jika diperlukan pada saat perlombaannya jauh atau berada di luar kota".

Faktor pendukung lainnya adalah sekolah itu sendiri. Sekolah berperan untuk membentuk karakter anak lebih baik lagi. Hal ini dilakukan melalui sosialisasi kepada orang tua murid. Sosialisasi yang dimaksud disini adalah tentang pentingnya pendidikan karakter diterapkan dirumah. Selanjutnya yang menjadi faktor pendukung dalam pelaksaaan pendidikan karakter di sekolah adalah siswa itu sendiri. Pembiasaan yang diterapkan di sekolah jika diikuti dengan baik maka tentu pendidikan karakter siswa akan berkembang dengan baik. Keberhasilan program budaya sekolah tak lepas dari dukungan seluruh stake holder dan komponen pendidikan yang memadai. Lebih lanjut Proses penanaman nilai sebagai implementasi pendidikan konservatif dilakukan melalui tahap inisiasi (penanaman), drill (pengulangan), pembiasaan (habituasi). Dalam pelaksanaannya penanaman mulai dilakukan dengan "sistem among" dan cara "tutwuri handayani". (Sartono, Muhadjir, dan Sumarno 2015).

Selain faktor pendukung, tedapat juga faktor penghambat yakni orang tua. Ketika sekolah melaksanakan sosialiasi pendidikan karakter dan meminta kehadiran orang tua di sekolah, yang terjadi justru sebaliknya. Alasan kesibukan menjadi dsar orang tua tidak hadir dan tidak mengikuti sosialiasi sehingga apa yang diharapkan pihak sekolah tidak dapat dilaksanakan dengan baik. Sebab bagaimanapun keberhasilan anak dalam pendidikan karakter di sekolah, tergantung juga pada pembiasaan orang tua di rumah. Sukadari dan Kuntoro dalam (Muhammad, dkk. 2018: 6) mengemukakan bahwa: peran guru dan orang tua serta masyarakat sangat diperlukan, terutama dalam memberikan contoh-contoh perilaku yang baik kepada anak. Guru dan orang tua harus selektif dalam memberikan input, seperti bahan bacaan atau cerita anak. Orang tua juga harus selektif dalam memilih acara televisi di rumah untuk anak karena pengaruh yang diterima pada masa anak-anak tidak mudah dihapus. Dari masa anak-anak sampai remaja karakter dibentuk secara luas melalui peniruan. Dari penjelasan di atas penulis mengambil kesimpulan bahwa faktor penghambat dalam penerapan budaya sekolah di SD Impres 19 Ambon terkendala akibat pihak sekolah serta keluarga yang belum terlibat aktif dalam melaksanakan budaya sekolah hal demikian tidak sejalan dengan pendapat di atas bahwa keberhasilan budaya seolah memerlukan dukungan dari semua pihak terutama pihak sekolah dan orang tua murid. 
Selanjutnya, sarana dan prasarana sekolah sangat penting dalam mendukung penerapan budaya sekolah. Infrastruktur sekolah yang tidak memadai menjadi penghambat dalam penerapan budaya sekolah. Misalnya ketika sekolah memberi aturan tidak boleh ada yang masuk barisan lagi ketika upacara bendera sedang berlangsung, akan sangat didukung jika sekolah dilengkapi dengan pagar sekolah. Dengan demikian siswa yang terlambat otomatis tidak dapat mengikuti upacara bendera. Lingkungan menjadi faktor penghambat berikutnya. Perkembangan teknologi dan pegaruhnya di lingkungan tempat tinggal siswa memberikan pengaruh yang besar terhadap karakter sisiwa. Di sekolah SD Inpres 19 Ambon sangat kurang sarana prasarana sekolah dan infrakstrukrur sekolah kemudian hambatan dari lingkungan seperti yang kita tau pesatnya perkembangan teknologi di bidang informasi, baik melalui media cetak, televisi, komunikasi dapat membawa dampak negatif terhadap perilaku siswa-siswi dan pengaruh budaya asing dan yang terakhir faktor penghamat dari siswa-siswi itu sendiri dimana masih ada beberapa siswa-siswi yang tidak mengikuti atau melanggar pembiasaan-pembiasaan yang diterapkan sekolah.

Ada beberapa upaya yang dilakukan dalam mengatasi kendala implementasi budaya sekolah dalam mewujudkan pendidikan karakter di SD Inpres 19 Ambon. Solusi sekolah dalam mengatasi kendala dari orang tua adalah dengan mensosialisasikan pentingnya pendidikan karakter melalui budaya sekolah yang diterapkan di SD Inpres 19 Ambon. Sebagai sarana antara guru dan orang tua untuk dapat bekerja sama dalam pemantuan pendidikan karakter anak. Upaya yang dilakukan dari sekolah bahwa guru harus konsisten dalam menerapkan budaya sekolah yang sudah terprogram di sekolah, guru juga harus menjadi teladan bagi siswa-siswinya, Pemanfaatan lingkungan sekolah untuk sarana belajar.

Upaya mengatasi dari lingkungan sama saja untuk orang tua yaitu dengan melakukan sosialisasi pentingnya pendidikan karakter diterapkan dilingkungan rumah. Seperti yang dikemukakan kepala sekolah.

"Sering mensosialisasikan kepada komite sekolah dan orang tua murid atas pentingnya pendidikan karakter yang diterapkan disekolah wajib diterapkan juga dirumah dan lingkungan masyarakat contohnya membatasi dan mengontrol anak saat memakai handphone, mendampingi dan membimbing anak saat menonton TV, mangatur jam belajar dan bermain anak".

Upaya mengatasi kendala dari para siswa adalah dengan memberikan teguran kemudian dibimbing anak tersebut. Berdasarkan hasil wawancara dengan guru dikatakan bahawa siswa yang bermasalah diberikan bimbingan oleh guru dan kemudian dikomunikasikan kepada orang tua dari siswa tersebut.

Upaya yang dilakukan dalam pelaksanaan implementasi budaya sekolah untuk membentuk karakter siswa tentu perlu dilakukan untuk tetap membudaya di sekolah tersebut. upaya-upaya yang dilakukan sekolah antara lain : dari orang tua wali dengan disosialisasikan pentingnya pendidikan karakter bagi siswa-siswi kepada orang tua. Dan orang tua juga diajak untuk dapat bekerja sama dalam membentuk karakter anak yang sesuai dengan pembudayaan yang diterapkan disekolah orang tua dapat 
membiasaakan kepada anaknya dirumah. Kemudian upaya mengatasi kendala dari pihak sekolah dengan konsisten membimbing siswa-siswi dan menjadi teladan dengan masih kurangnya fasilitas yang ada disekolah.

Upaya yang dilakukan berikutnya yaitu untuk mengatasi hambatan dari lingkungan Sering mensosialisasikan kepada komite sekolah dan orang tua murid atas pentingnya pendidikan karakter yang diterapkan disekolah wajib diterapkan juga dirumah dan lingkungan masyarakat contohnya membatasi dan mengontrol anak saat memakai handphone, mendampingi dan membimbing anak saat menonton TV, mangatur jam belajar dan bermain anak. Dan yang terakhir upaya mengatasi hambatan dari peserta didik, dengan dilakukannya teguran jika masih ada peserta didik yang melanggar juga guru akan melakukan bimbingan terhadap anak tersebut dan jika masih melanggar juga pihak sekolah akan memanggil orang tua dari anak tersebut untuk dapat memberikan bimbingan masalah apa yang ada kemudian dicari solusi bersama-sama sesuai dengan masalah yang ada dalam diri anak tersebut.

Sekolah tidak saja diharapkan bisa mengelola potensi para peserta didik secara maksimal sehingga menghasilkan lulusan-lulusan yang berkualitas, tetapi juga terkait nilai-nilai yang dikembangkan di sekolahnya. Dengan demikian perlunya perubahan cara pandang serta kerja sama yang baik dari kepala sekolah, guru, administrator, murid, orang tua, dan masyarakat sebagai langkah untuk merubah sistem, baik tindakan maupun proses pencapaian tujuan sekolah. Dengan adanya perubahan ini maka implikasinya sekolah akan merancang apa yang mesti dilakukan dan berusaha memahami tindakan-tindakan yang dirancangnya sebagai sesuatu yang disepakati bersama. Dengan kata lain tindakan ini mendorong untuk terciptanya budaya sekolah.

Implementasi budaya sekolah di SD Inpres 19 Ambon pada akhirnya mampu menjawab tantangan implementasi budaya sekolah mewujudkan pendidikan karakter. Hal ini selaras dengan pendapat yang dikemukakan oleh Zamroni (dalam Kuriniawan, 2013: 123-124), bahwa budaya sekolah merupakan suatu pola asumsi-asumsi dasar, nilai-nilai, keyakinan-keyakinan, kebiasaan-kebiasaan yang dipegang bersama oleh seluruh warga sekolah, yang diyakini dan telah terbukti dapat dipergunakan untuk menghadapi berbagai problem dalam beradaptasi dengan lingkungan yang baru dan melakukan integrasi internal sehingga pola nilai dan asumsi tersebut dapat diajarkan kepada anggota dan generasi baru agar mereka memiliki pandangan yang tepat bagaimana mereka seharusnya memahami,berpikir, merasakan, dan bertindak menghadapi berbagai situasi dan lingkungan yang ada.

Budaya sekolah adalah sekumpulan nilai yang melandasi perilaku, tradisi, kebiasaan keseharian, dan simbol-simbol yang dipraktikkan oleh seluruh masyarakat sekitar sekolah. Seperti halnya yang dilakukan oleh SD Inpres 19 Ambon sehingga mereka mampu memahami, berfikir serta bertindak sesuai dengan pembiasaan melalui budaya sekolah yang di terapkan yaitu menanamkan nilai-nilai religius, nasionalisme, peduli sosial, peduli lingkungan dan kemandirian yang bukan saja di ajarkan secara teori tetapi anak-anak di ajak merasakan dan mempraktekkan dalam kehidupan sekolah maupun masyarakat.

Zamroni dalam Pendi susanto, (2016:95) mengemukanan pentingnya sekolah memiliki budaya atau kultur. Sekolah sebagai suatu organisasi harus memiliki: (1) 
kemampuan untuk hidup, tumbuh berkembang dan melakukan adapatasi dengan berbagai lingkungan yang ada, dan (2) integrasi internal yang memungkinkan sekolah untuk menghasilkan individu atau kelompok yang memiliki sifat positif. Oleh karenanya suatu organisasi termasuk sekolah harus memiliki pola asumsi-asumsi dasar yang dipegang bersama seluruh warga sekolah. Budaya sekolah merupakan penjabaran dari nilai yang diterapkan di sekolah, norma yang ada dan diberlakukan di sekolah, serta harapan dan kebiasaan yang menggambarkan interaksi timbal balik antara satu anggota dengan lainnya. Pada dasarnya budaya sekolah sama dengan budaya organisasi lainnya, namun sekolah mempunyai fokus terhadap menyediakan pembelajaran bermutu bagi peserta didiknya, yang mana hal tersebut menjadi pembeda sekolah dengan organisasi-organisasi lainnya. Budaya sekolah dapat tercermin dalam nilai yang dianutnya, sikap yang dimilikinya, kebiasaan-kebiasaan yang ditampilkannya, dan tindakan yang ditunjukkan oleh seluruh personil sekolah yang membentuk satu kesatuan khusus dari sistem sekolah.

Jadi sangat penting sebuah sekolah memiliki budaya atau kultur. Sekolah harus memiliki pola asumsi-asumsi dasar yang dipegang bersama seluruh warga sekolah. Budaya sekolah tersebut yang menjadi pembeda dengan sekolah-sekolah yang lainnya dalam memahami, berfikir serta bertindak agar kelak melalui budaya sekolah menjadi bekal untuk anak dalam kehidupan bermasyarakat berbangsa dan bernegara.

\section{KESIMPULAN}

Hasil penelitian yang diperoleh menunjukan bahwa, program-program pembudayaan yang ada di sekolah SD Inpres 19 Ambon telah diterapkan dengan baik oleh sekolah. Program budaya sekolah diantaranya budaya religius, budaya kemandirian, budaya nasionalisme, budaya peduli sosial dan budaya peduli lingkungan saat dijalankan dengan baik oleh warga sekolah, maka karakter siswa bertumbuh dengan baik pula. Peran orang tua siswa sangat penting dalam mendukung kegiatan-kegiatan sekolah yang positif misalnya mengikuti lomba-lomba cerdas cermat, maupun baris berbaris sehingga program budaya tersebut mampu membawa siswa-siswi yang ada di SD Inpres 19 Ambon memiliki karakter yang baik sesuai dengan norma dan adat istiadat yang ada.

\section{DAFTAR PUSTAKA}

Anggraini, M.S.A.,2017. Implementasi pendidikan karakter melalui budaya sekolah di SD \& kotagede 3 Yogyakarta tahun Ajaran 2016/2017. Jurnal Pendidikan Ke-SD-an, Vol. 3, Nomor 3.

Agus, 2012. Pendidikan Karakter berbasis Nilai \& Etika di Sekolah. Yogyakarta: Ar-Ruzz Media.

Agustian, Ary, G. 2008. Rahasia Sukses Membangun ESQ Power, Sebuah Inner Journey melalui Ihsan. Jakarta: Penerbit Arga 
Hamalik, 2008. Kurikulum dan Pembelajaran. Jakarta: Sinar Grafika

Kemendiknas, 2010. Pengembangan Pendidikan Budaya dan Karakter Bangsa. Jakarta: Puskur-Bulitbang.

Kesuma, D. dkk., 2013. Bahan Ajar Pendidikan Profesi Guru Sekolah Dasar. Bandung: Program Studi Pendidikan Guru Sekolah Dasar.

Komalasari dan Saripudin, 2017. Pendidikan Karakter Konsep dan Aplikasi Living Values Education. Bandung: PT Refika Aditama.

Komariah, A dan Triatna, C., 2005. Visionary Leadership Menuju Sekolah Efektif. Jakarta: Bumi Aksara

Lickona, Th., 2004. Educating for Character, How Our Schools Can Teach Respect and Responsibility. New York: Bantam Books

Lickona. Th., 2013. Pendidikan Karakter-Panduan Lengkap Mendidik Siswa Menjadi Pintar dan Baik (Terjemahan dari Educating for Character, 2008 oleh Lita S), Bandung: Nusa Mesia.

Samani, Muchlas dan Hariyanto. 2011. Konsep dan Model Pendidikan Karakter. Bandung : PT Remaja Rosda Karya .

Saripudin. 2010. Pendidikan Karakter Konsep dan Aplikasi Livin Values Education. Bandung: PT. Refika Aditama.

Tirtarahardja, Umar dan La Sulo., 1994. Pengantar Pendidikan. Jakarta: Dirjen Dikti Depdikbud.

Tilaar, H.A.R. 2000. Paradigma Baru Pendidikan Nasional. Jakarta: Rineka Uyoh,S., dkk. 2006. Pedagogik, Bandung : UPI PRESS

Wiyani, N. A., 2012. Pendidikan Karakter dan Kepramukaan. Yogyakarta: Citra Aji Parama.

Yaumi, M., 2014. Pendidikan Karakter Landasan, Pilar, dan Implementasi. Kencana, Jakarta.

Zamroni, 2000. Paradigma Pendidikan Masa Depan. Yogyakarta: Bigraf

Zubaedi, 2015. Desain Pendidikan Karakter. Jakarta: Prenamedia Group Pubilshing. 